\title{
Analysis of the global tall buildings stability in flat slabs considering the soil structure interaction
}

\section{Análise da estabilidade global de edifícios altos em lajes lisas considerando a interação solo-estrutura}

E. C. ALVES elcio.calves1@gmail.com https://orcid.org/0000-0001-6971-2645

L. A. FEITOSA leofeitosa@gmail.com https://orcid.org/0000-0003-4666-6572

\begin{abstract}
The global stability of tall reinforced concrete buildings made up of flat slabs is guaranteed, among other factors, by the existence of considerably rigid elements such as elevator cores and stairways. Such rigid cores recurrently have the "L" or "U" format because they fit the architectural design better. However, it should be emphasized the considerable relevance and influence of the slabs transversal bending stiffness in the building stability. The slabs act in conjunction with the columns in the building stability, in the so-called rigid diaphragm effect. That is, they combine the horizontal displacements in each floor and promote a partial restriction to the warping of the rigid cores and the rotation of the ends of the columns, thus reducing the horizontal displacements and the effects of 2 nd order. In contrast the slabs transversal bending stiffenes, it should be emphasized the importance of considering the soil-structure interaction (ISE) in the buildings stability. In buildings formed by flat slabs ISE gains considerable relevance because of their characteristics, ie such buildings are particularly sensitive to the influences of soil-structure interaction. In this work, emphasis is placed on the influence of cross-bending rigidity on slabs and on Soil-Structure Interaction in the analysis and verification of the global stability of multi-storey buildings formed by flat slabs and rigid cores.
\end{abstract}

Keywords: stability, global, interaction, soil structure.

\section{Resumo}

A estabilidade global de edifícios altos de concreto armado formados por lajes planas é garantida, entre outros fatores, pela existência de elementos consideravelmente rígidos, como os núcleos de elevadores e regiões das escadas. Tais núcleos rígidos apresentam recorrentemente o formato de "L" ou "U" por se adequarem melhor ao projeto arquitetônico. No entanto, deve-se ressaltar a considerável relevância e influência da rigidez à flexão transversal das lajes na estabilidade da edificação. As lajes atuam em conjunto com os pilares na estabilidade do edifício, no denominado efeito de diafragma rígido. Ou seja, elas compatibilizam os deslocamentos horizontais em cada pavimento e promovem uma restrição parcial ao empenamento dos núcleos rígidos e ao giro das extremidades dos pilares, reduzindo assim os deslocamentos horizontais e os efeitos de $2^{\mathrm{a}}$ ordem. Em contraponto à rigidez à flexão transversal das lajes, deve-se ressaltar a importância da consideração da interação solo-estrutura (ISE) na estabilidade das edificações. Em edifícios formados por lajes planas a ISE ganha uma relevância considerável, devido às suas características, isto é, tais edificações são particularmente sensíveis às influências da interação solo-estrutura. Neste trabalho dá-se ênfase à influência da rigidez à flexão transversal das lajes e à Interação Solo-Estrutura na análise e verificação da estabilidade global de edifícios de múltiplos andares formados por lajes planas e núcleos rígidos.

Palavras-chave: estabilidade, global, interação, solo-estrutura. 


\section{Introduction}

The large growth of construction verticalization in Brazil required more detailed design criteria to ensure the structural safety of buildings. In this context, one of the relevant factors in the analysis of the global stability of the structures is the Gamma $z\left(\gamma_{z}\right)$ parameter introduced by Franco and Vasconcelos [1]. On the other hand, since its revision in 2003 ABNT NBR 6118 has adopted the Alpha $(\alpha)$ parameter as a parameter for the analysis of the global stability of tall buildings.

A building system that has been widespread is the use of flat slabs, prestressed or not, being one of its most advantageous factors the absence of beams. On the other hand, this type of structural system has a relevant disadvantage, the reduction of the rigidity to horizontal displacements, leading to questions about the global stability of the structure. In this type of building the most commonly used bracing system is that of rigid cores, formed by "U" or "L" shaped wall columns, usually located in the area of the stairs and elevator shafts. These elements have high rigidity and, combined with the other columns, guarantee the global stability of the building. The prestressed slabs, in turn, act together with the columns (rigid diaphragm effect), stabilizing the structure. Because they have active reinforcement, these slabs have a low level of cracking for recurring requests in the structure, so it would not be wrong to assume that the reduction coefficients that take into account the physical nonlinearity of the slabs, provided in ABNT NBR 6118: 2014 [2], could present less conservative values.

Important research in the analysis of global stability has been done. Among the most recent works, we can highlight Passos et al. [3], Freitas et al. [4], Feitosa and Alves [5] and Kimura [6]. However, in these works, the global instability parameter was studied considering only the superstructure, that is, the effect of soil deformations on superstructure displacements was not considered.

In view of the above, this paper aims to present a study of the parameter $\gamma_{z}$ taking into account the effect of soil-structure interaction. For this, two building models were studied, the first with the ceiling height of the type defined by the ratio $\mathrm{H} / 4$, in which $\mathrm{H}$ corresponds to the
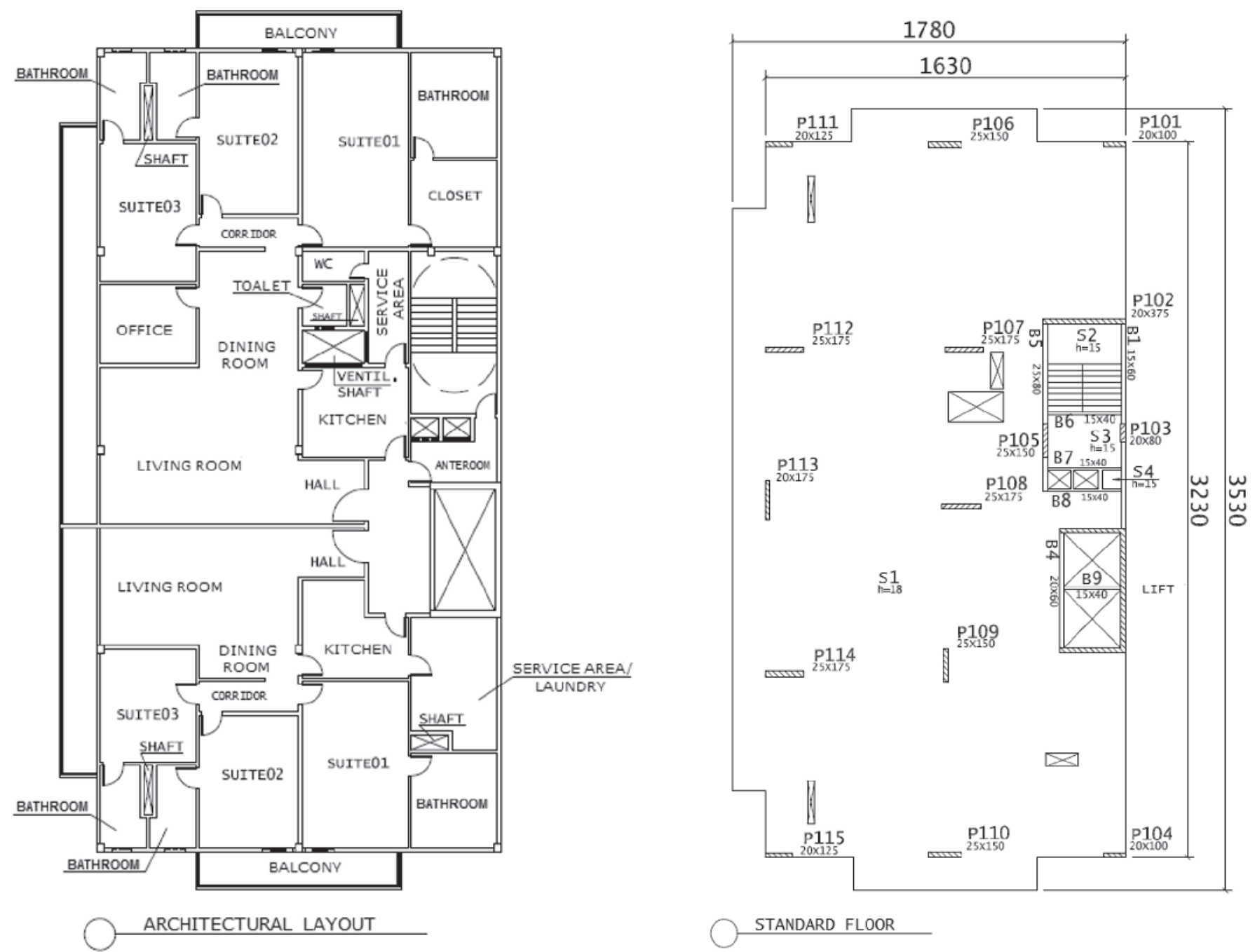

Figure 1

Architectural layout and structural launch of the standard floors (levels) 
total height of the building, while the ceiling height of the second was given by the ratio $\mathrm{H} / 4$. 6 That is, the height of the building corresponds to 4 and 6 times the horizontal dimension in plan, respectively. For the analyzes the commercial software CAD / TQS was used.

\subsection{Justification}

The instability coefficient $\gamma_{z}$, introduced by Franco and Vasconcelos [1], measures the sensitivity of the structure to second order effects, and can also be used to increase global first order efforts due to horizontal loads to obtain approximate second order effects. The coefficient $\gamma_{z}$ is defined by:

$\gamma_{z}=\frac{1}{1-\frac{\Delta M_{d}}{M_{d}}}$

In which :

- $\Delta \mathrm{M}_{\mathrm{d}}$ : It is the sum of the products of all vertical forces acting on the structure by the horizontal displacements applied at their respective points, which are obtained in the first order analysis;

- $\mathrm{M}_{1 \mathrm{~d}}$ : It is the tipping moment, that is, the sum of the moments produced by the horizontal forces in relation to the base of the structure.

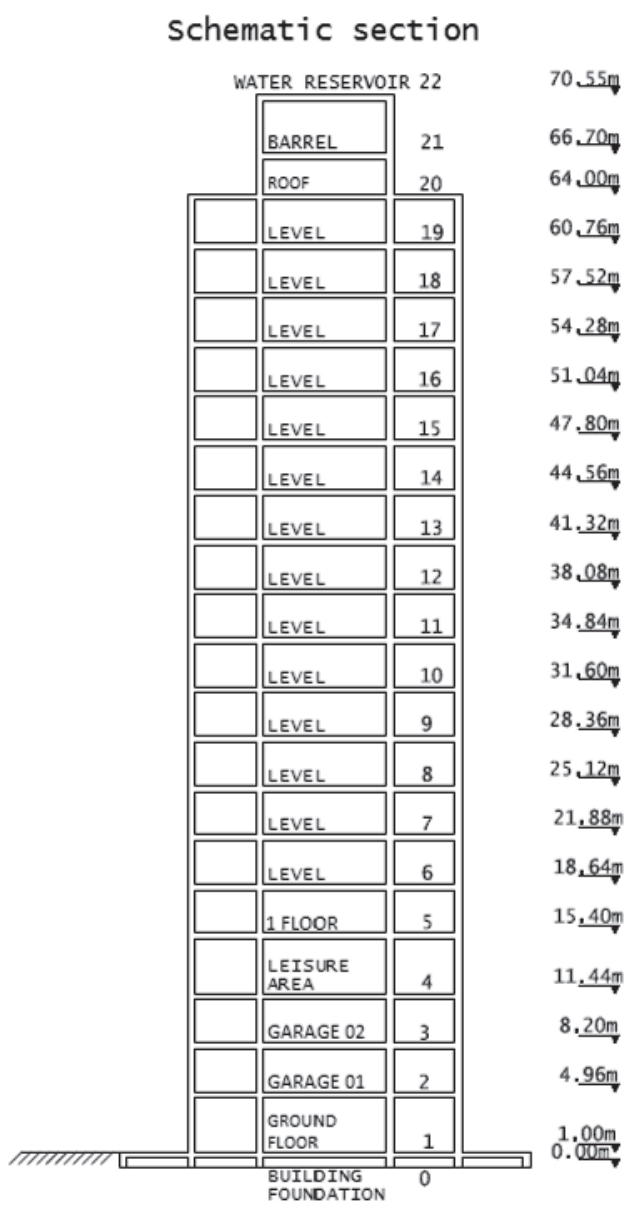

Figure 2

Schematic section - first model series $(h=H / 4)$
Recent works on tall buildings for global instability include Passos et al. [3], Freitas et al. [4] and Feitosa and Alves [5]. In these works the parameter $\gamma_{z}$ is analyzed for different design situations and their influences. However, studies considering the effect of soil-structure interaction and how much this effect impacts on this parameter are scarce. Thus, the present work will contribute to the discussion of the parameters $\gamma_{z}$ e $\alpha$, and how they are impacted when the effect of the iteration of the ground structure is considered in tall building projects with smooth slabs.

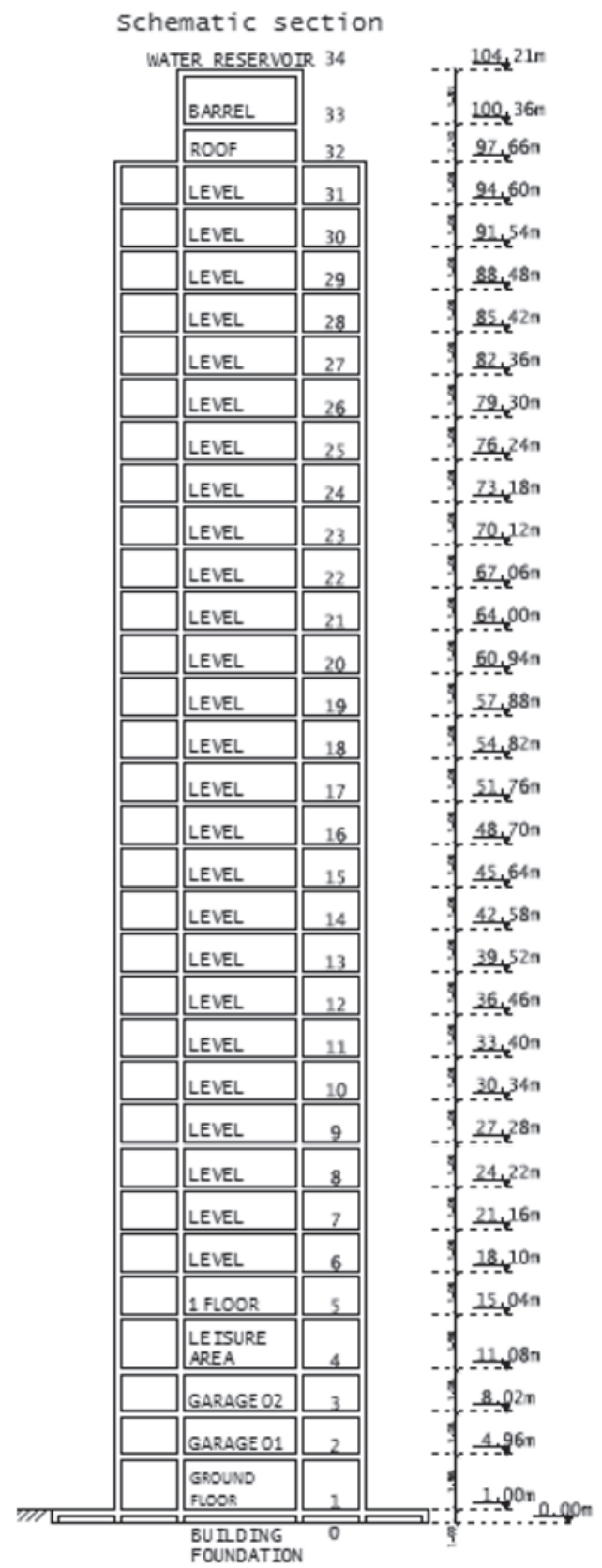

Figure 3

Schematic section - second series of models $(\mathrm{h}=\mathrm{H} / 6)$ 


\section{Analysis models}

For the presentation and discussion of the results, two series of models were studied. The difference between the series occurs in the ratio between the total height of the building $(\mathrm{H})$ and the size of the building in plan. Thus, one series has $\mathrm{H} / 4$ ratio while the other is $\mathrm{H} / 6$. Figure 1 shows the building in plan and Figures 2 and 3 show the schematic section of the analyzed buildings. Figure 4 shows the floor plan of the $\mathrm{H} / 6$ Building Model. The models of the first series have the floors: Ground Floor, Garage 1, Garage 2, leisure area, 1st Floor, 14 standard floors (levels), Roof and Attic, with ceiling height being 3.24 meters. The second series of models, with ratio $\mathrm{H} / 6$, was modeled from the first series, changing the number of standard floors to 26 , and the ceiling height of these floors was reduced to 3.06 meters, as can be seen in Figure 3 .

The characteristic strength of concrete of the structural elements was:

- Beams and slabs: $30 \mathrm{MPa}$;

- Columns: $40 \mathrm{MPa}$;

- Foundation elements (piling crown block): $30 \mathrm{MPa}$.

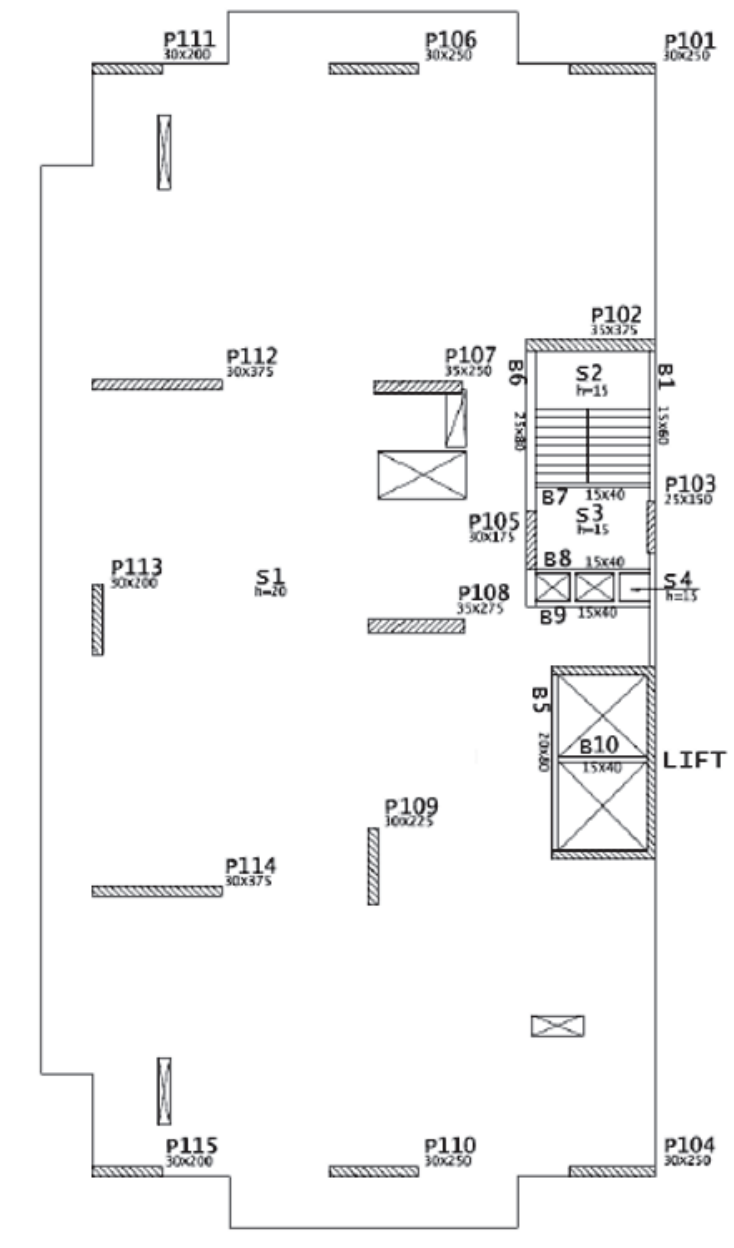

FLOOR PLAN OF STANDARD FLOOR (LEVEL) - MOD0200

\section{Figure 4}

Floor plan of levels of second series model
Table 1

Loads distributed by area

\begin{tabular}{ccc}
\hline Paving & $\begin{array}{c}\text { Dead load } \\
{\left[\mathrm{kN} / \mathrm{m}^{2}\right]}\end{array}$ & $\begin{array}{c}\text { Live load } \\
{\left[\mathrm{kN} / \mathrm{m}^{2}\right]}\end{array}$ \\
\hline Ground floor & 1.75 & 3.0 \\
Garage 1 & 1.0 & 3.0 \\
Garage 2 & 1.0 & 3.0 \\
Leisure area & 2.0 & 3.0 \\
$1^{\circ}$ floor & 1.15 & 1.5 \\
Floors (levels) & 1.15 & 1.5 \\
Roof & 1.0 & 0.5 \\
\hline
\end{tabular}

The characteristics considered for the determination of wind loads were:

Basic wind speed: 32 metre/sec;

- $\mathrm{S} 1$ - Terrain topographic factor: 1;

- S2 - Roughness Category: V - Terrain with numerous obstacles, large, high and little spaced.

For the dimensioning of the columns and foundation elements, the reduction in living loads provided for in item 2.2.1.8 of ABNT NBR 6120: 1980 [7] was considered according to Table 4 of the same standard. The loads distributed by area used in the models are presented in Table 1 and follow the recommendations of ABNT NBR 6120: 1980 [7].

The dead loads considered are due to regularization and floor finishing as well as waterproofing, in the case of the roof and leisure area. Regarding masonry loads, the following values were adopted:

External and internal walls in ceramic blocks: $5.5 \mathrm{kN} / \mathrm{m}$;

Drywall internal walls: $1.6 \mathrm{kN} / \mathrm{m}$.

For the soil-structure interaction analysis we used the ground survey profile, shown in Figure 5.

\section{Results and reviews}

\subsection{Results of the first template series}

The starting point for the analysis of the models of each series was the development of a model (MOD0100) that presented the value of the instability parameter $\gamma_{z}$ as close as possible to the limit indicated by ABNT NBR 6118: 2014 [2], which is 1.3. Through a sequence of attempts, in which the cross sections of the building's columns were changed, the value of 1.292 (for the most critical wind case) was obtained, as can be seen in Table 2.

Based on the results of Feitosa and Alves [5] and Passos et al. [3], a new model was defined where all the parameters that effectively contributed to the improvement of the $\gamma_{z}$ of the building were used. The MOD0101 model presents the coefficients that simulate the physical nonlinearity (PN) of beams and slabs with values less conservative than those adopted in the reference model MOD0100 and foreseen in ABNT NBR 6118: 2014 [2]. For all beams was adopted the value of 0.7 , which was indicated by ABNT NBR 6118: 2007 when considering beams and columns as components of the bracing system. For the slabs, assuming the premise of prestressed slabs, with a crack level lower than that of conventional reinforced concrete slabs, the value of 0.5 was adopted. For the columns, the value remained 0.8 . 


\section{SURVEY 1}

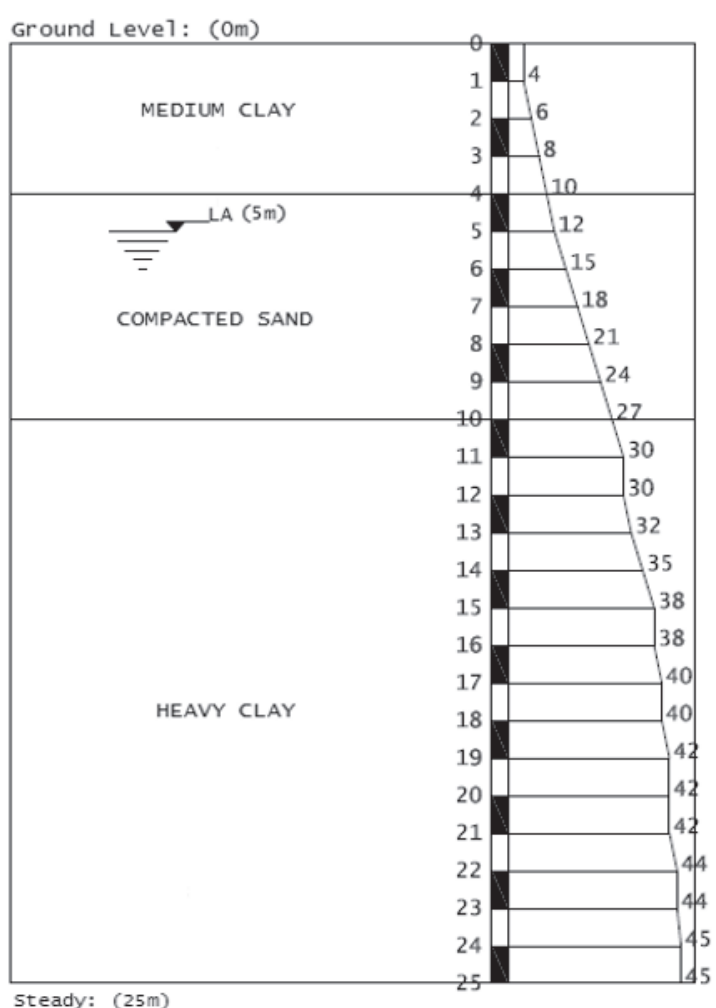

\section{SURVEY 2}

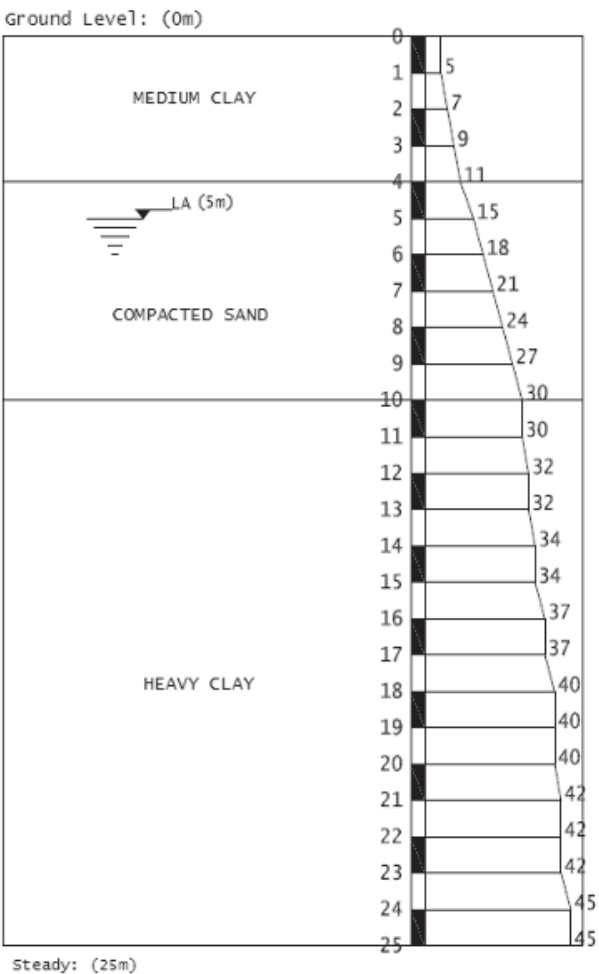

\section{Figure 5}

Surveying profiles

The results of MOD0101 for the instability and quantitative parameters in the columns are presented in Table 2 and Table 3 respectively.

The analysis of the results in Table 2 indicates that the change in the criteria adopted in MOD0100 produced a considerable reduction in the value of the coefficient $\gamma_{z}$ and of the parameter $\alpha$. The maintenance of the horizontal displacement values was expected, since, for the ELS verification, the PN coefficient of the elements did not change. This result again demonstrates the relevance of the slab transverse flexural stiffness to the stability of the structure, because, due to the low number of beams present, the reduction obtained should be attributed in large part to the increased

\section{Table 2}

Results for the instability coefficients and displacements for first template series

\begin{tabular}{|c|c|c|c|c|c|c|}
\hline Wind & $\begin{array}{l}\text { Coefficient } \\
\text { of stability }\end{array}$ & MOD0100 & MOD0101 & MOD102 & MOD103 & MOD104 \\
\hline $90^{\circ}-270^{\circ}$ & Gamma Z & 1.292 & 1.225 & 1.307 & 2.11 & 1.268 \\
\hline $0^{\circ}-180^{\circ}$ & Gamma Z & 1.183 & 1.15 & 1.176 & 1.769 & 1.243 \\
\hline $90^{\circ}-270^{\circ}$ & Alpha & 1.401 & 1.253 & 1.433 & 2.004 & 1.254 \\
\hline $0^{\circ}-180^{\circ}$ & Alpha & 1.01 & 0.938 & 0.98 & 0.98 & 1.15 \\
\hline \multicolumn{7}{|c|}{ Displacements } \\
\hline $90^{\circ}-270^{\circ}$ & $\begin{array}{l}\text { Global disp. } \\
{[\mathrm{cm}]}\end{array}$ & $\begin{array}{c}2.27 \\
(H / 3102)\end{array}$ & $\begin{array}{c}2.27 \\
(H / 3102)\end{array}$ & $\begin{array}{c}2.39 \\
(H / 2957)\end{array}$ & $\begin{array}{c}4.04 \\
(H / 1748)\end{array}$ & $\begin{array}{c}1.93 \\
(H / 3503)\end{array}$ \\
\hline $0^{\circ}-180^{\circ}$ & $\begin{array}{c}\text { Global displ. } \\
{[\mathrm{cm}]}\end{array}$ & $\begin{array}{c}0.92 \\
(H / 7670)\end{array}$ & $\begin{array}{c}0.92 \\
(H / 7670)\end{array}$ & $\begin{array}{c}0.94 \\
(H / 7505)\end{array}$ & $\begin{array}{c}1.59 \\
(H / 4436)\end{array}$ & $\begin{array}{c}0.75 \\
(H / 8977)\end{array}$ \\
\hline $90^{\circ}-270^{\circ}$ & $\begin{array}{l}\text { Local disp. } \\
{[\mathrm{cm}]}\end{array}$ & $\begin{array}{c}0.25 \\
(h / 1276)\end{array}$ & $\begin{array}{c}0.25 \\
(h / 1276)\end{array}$ & $\begin{array}{c}0.23 \\
(h / 1662)\end{array}$ & $\begin{array}{c}0.33 \\
(h / 1165)\end{array}$ & $\begin{array}{c}0.23 \\
(h / 1703)\end{array}$ \\
\hline $0^{\circ}-180^{\circ}$ & $\begin{array}{l}\text { Local disp. } \\
{[\mathrm{cm}]}\end{array}$ & $\begin{array}{c}0.22 \\
(h / 1495)\end{array}$ & $\begin{array}{c}0.22 \\
(h / 1495)\end{array}$ & $\begin{array}{c}0.09 \\
(h / 4213)\end{array}$ & $\begin{array}{c}0.22 \\
(h / 1460)\end{array}$ & $\begin{array}{c}0.10 \\
(h / 3786)\end{array}$ \\
\hline
\end{tabular}


Table 3

Quantitative analysis for the first series model

\begin{tabular}{ccccccc} 
& Quantities & MOD0100 & MOD0101 & MOD102 & MOD103 & MOD104 \\
\hline \multirow{2}{*}{$\begin{array}{c}\text { Forms } \\
\left(\mathrm{m}^{2}\right)\end{array}$} & Columns & 5234 & 5234 & 5234 & 5234 & 6815 \\
& Total & 19118 & 19118 & 19118 & 19118 & 20905 \\
& Rate & $27.38 \%$ & $27.38 \%$ & $27.38 \%$ & $27.38 \%$ & $32.60 \%$ \\
\hline \multirow{2}{*}{$\begin{array}{c}\text { Concrete volume } \\
\left(\mathrm{m}^{3}\right)\end{array}$} & Columns & 531 & 531 & 531 & 531 & 912 \\
& Total & 2943 & 2943 & 2943 & 2943 & 3583 \\
& Rate & $18.04 \%$ & $18.04 \%$ & $18.04 \%$ & $18.04 \%$ & $25.45 \%$ \\
\hline
\end{tabular}

stiffness given to the slabs by adopting a value equal to $0.5 \mathrm{EI}$ instead of $0.3 \mathrm{El}$ for stiffness. This result meets the expectations of Feitosa and Alves [5]. Regarding the quantitative values, they were the same, considering that the sections of the columns remained unchanged. The MOD0102 model deals with a refinement of the mesh in the slab-column connection area , a subject to be analyzed in detail in future research. However, its influence on the global stability of the structure, especially in slabs supported directly on columns, as can be seen on Table 2 . The values adopted for the dividers were:

- Capital bending inertia divider: 2;

- Bending inertia divider on intermediate column support: 5.

As can be seen in Table 2, the refinement of the mesh led to an increase in instability parameters of $6.3 \%$ in parameter $\gamma_{z}$ in the wind direction $90^{\circ}-270^{\circ}$ and $12.6 \%$ in parameter $\alpha$ in the same direction. The results indicate that the system standard values can generate values below those that should be predicted. Quantities remain unchanged in this model, as shown in Table 3.

In model MOD0103, the analysis module SISE - Solo-Structure Interaction System of the CAD / TQS program was used. For this, the foundation elements were included: plinth beams, piles and foundation blocks which, together with the surveying profiles, were used to calculate the vertical and horizontal reaction coefficients to be incorporated into the space frames. In this model were considered precast piles with a diameter of $40 \mathrm{~cm}$ for the tower columns and a diameter of $25 \mathrm{~cm}$ for the columns that "die" at the end of the basement. The structural capacity of the piles was taken from commercial catalogs, while the capacity of the soil pile system for the adopted length was estimated from the Aoki-Velloso method [8]. A safety factor of two was adopted to determine the permissible load capacity of piles, as recommended byABNT NBR 6122: 2010 [9]. The MOD0103 results for the instability and displacement parameters are presented in Table 2 and quantitative in Table 3.
The results of MOD0103 show the great influence of Soil-Structure Interaction (SSI) on the analysis of horizontal displacements and structure stability. Comparing the results, it can be said that considering the SSI in the sizing of the structure leads to its flexibility, similar to not considering the rigidity to the transverse flexion of the slabs. However, while not considering the rigidity of the slabs leads to conservative results, as not all elements of the structure are considered for determining their rigidity, ignoring the SSI leads to results against safety.

Finally, we sought to develop a model that included all the parameters analyzed here, which contributed to the stabilization of the structure, in addition to the SSI, as this is fundamental and indispensable in structural analysis (MOD104). The results found for the instability and quantitative parameters are presented in Table 2 and Table 3 respectively.

A sequence of attempts was performed until the results presented in Table 3 were obtained. In addition to the adoption of all favorable parameters, the cross sections of the columns underwent successive manual revisions until reaching the presented results.

It is noteworthy that the total values of concrete consumption and forms presented in Table 3, include the quantities of plinth beams and piles foundation blocks, elements not considered in the MOD0100 reference model. However, it is possible to compare the concrete volume quantities of the columns between the models. In the MOD0100 model the concrete volume of the columns was 531 cubic meters, while the MOD0104 model had a quantity of 912 cubic meters, a percentage increase of $71.75 \%$ in the concrete volume.

\subsection{Results of the second template series}

For the second series models, the $\mathrm{H} / 6$ ratio was adopted, and the parameters were varied as shown in Table 4. The reference

\section{Table 4}

Description of proposed model parameters - second series

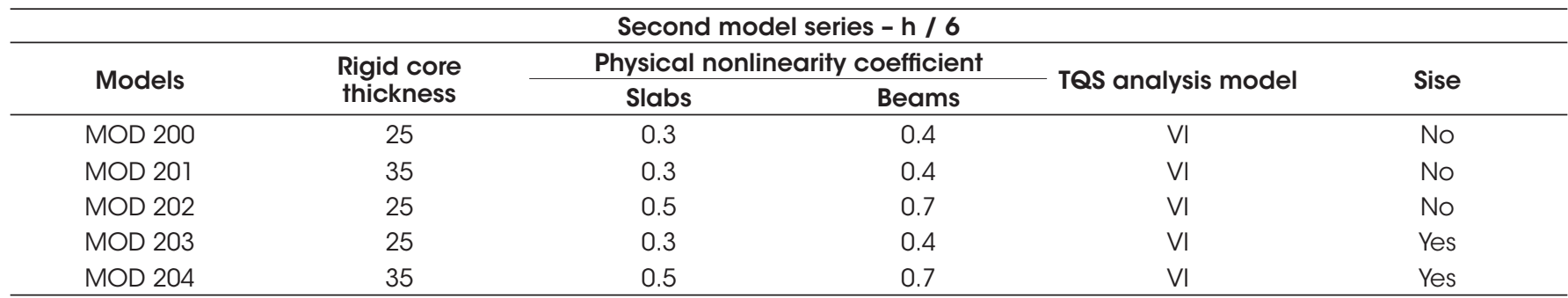


Table 5

Results for the instability and displacement coefficients second template series

\begin{tabular}{|c|c|c|c|c|c|c|}
\hline Wind & $\begin{array}{l}\text { Coefficient } \\
\text { of stability }\end{array}$ & MOD0200 & MOD0201 & MOD202 & MOD203 & MOD204 \\
\hline $90^{\circ}-270^{\circ}$ & Gamma Z & 1.287 & 1.282 & 1.208 & 1.699 & 1.268 \\
\hline $0^{\circ}-180^{\circ}$ & Gamma Z & 1.226 & 1.279 & 1.17 & 1.481 & 1.206 \\
\hline $90^{\circ}-270^{\circ}$ & Alpha & 1.286 & 1.203 & 1.115 & 1.686 & 1.207 \\
\hline $0^{\circ}-180^{\circ}$ & Alpha & 1.051 & 1.018 & 0.93 & 1.385 & 1.023 \\
\hline \multicolumn{7}{|c|}{ Displacements } \\
\hline $90^{\circ}-270^{\circ}$ & $\begin{array}{l}\text { Global disp. } \\
{[\mathrm{cm}]}\end{array}$ & $\begin{array}{c}3.10 \\
(H / 3364)\end{array}$ & $\begin{array}{c}3.02 \\
(H / 3449)\end{array}$ & $\begin{array}{c}3.10 \\
(H / 3364)\end{array}$ & $\begin{array}{c}5.18 \\
(H / 2013)\end{array}$ & $\begin{array}{c}3.66 \\
(H / 2849)\end{array}$ \\
\hline $0^{\circ}-180^{\circ}$ & $\begin{array}{c}\text { Global displ. } \\
{[\mathrm{cm}]}\end{array}$ & $\begin{array}{c}0.21 \\
(H / 1451)\end{array}$ & $\begin{array}{c}1.28 \\
(H / 8134)\end{array}$ & $\begin{array}{c}1.37 \\
(H / 7634)\end{array}$ & $\begin{array}{c}1.89 \\
(H / 5519)\end{array}$ & $\begin{array}{c}1.27 \\
(H / 8174)\end{array}$ \\
\hline $90^{\circ}-270^{\circ}$ & $\begin{array}{l}\text { Local disp. } \\
{[\mathrm{cm}]}\end{array}$ & $\begin{array}{c}1.36 \\
(h / 7636)\end{array}$ & $\begin{array}{c}0.21 \\
(h / 1451)\end{array}$ & $\begin{array}{c}0.21 \\
(h / 1541)\end{array}$ & $\begin{array}{c}0.31 \\
(h / 1244)\end{array}$ & $\begin{array}{c}0.25 \\
(h / 1514)\end{array}$ \\
\hline $0^{\circ}-180^{\circ}$ & $\begin{array}{l}\text { Local disp. } \\
{[\mathrm{cm}]}\end{array}$ & $\begin{array}{c}0.20 \\
(h / 1558)\end{array}$ & $\begin{array}{c}0.2 \\
(h / 1558)\end{array}$ & $\begin{array}{c}0.20 \\
(h / 1558)\end{array}$ & $\begin{array}{c}0.12 \\
(h / 3159)\end{array}$ & $\begin{array}{c}0.12 \\
(h / 3148)\end{array}$ \\
\hline
\end{tabular}

\section{Table 6}

Quantitative analysis for the first series model

\begin{tabular}{ccccccc} 
& Quantities & MOD0200 & MOD0201 & MOD202 & MOD203 & MOD204 \\
\hline \multirow{2}{*}{$\begin{array}{c}\text { Forms } \\
\left(\mathrm{m}^{2}\right)\end{array}$} & Columns & 10788 & 1552 & 10788 & 10788 & 13699 \\
& Total & 31732 & 5571 & 31732 & 32043 & 36898 \\
\hline \multirow{2}{*}{$\begin{array}{c}\text { Concrete volume } \\
\left(\mathrm{m}^{3}\right)\end{array}$} & Rate & $34.00 \%$ & $27.86 \%$ & $34.00 \%$ & $33.67 \%$ & $37.13 \%$ \\
& Columns & 1447 & 10767 & 1447 & 1447 & 2251 \\
& Total & 5468 & 31697 & 5468 & 5496 & 6438 \\
\hline
\end{tabular}

model of this series was named MOD0200 and the results of the instability parameters of this model are presented in Table 5 and the quantities for the columns in Table 6.

For the MOD0201 model, the thickness of 35 centimeters was adopted, instead of the 25 centimeters adopted in the reference model for the rigid core. The results of this model are presented in Table 5 and Table 6 for the instability and quantitative parameters of the columns respectively.

It is observed that the reduction in the value of the coefficient $\gamma_{z}$ discrz was slight, on the order of $0.4 \%$. This result differs significantly from that obtained with the analogous model of the first series. As the number of floors increases, the other columns of the structure also had their cross-sections increased, so that the contribution of the core stiffness to the global stiffness of the structure, which in this case also includes the transverse flexural stiffness of the slabs, decreased significantly compared to first series models.

It should be noted, however, that in the CAD / TQS program the rigid core is simulated as a bar with axial and flexural stiffness equivalent to that of the core cross section (Feitosa [11]), and that the effect of partial restriction to the bending provided by the lintels and flat slab was not considered for the calculation of horizontal displacements, which is an important limitation of the program.

In the MOD0202 model, the values of the physical nonlinearity coefficients (PN) for the beams and slabs were redefined, in an analogous analysis to the one developed in MOD0101. Again, the value of 0.7 was adopted for the beams and 0.5 for the slabs. Results are presented in Table 5 and Table 6.
The results of Table 5 reaffirm the significant influence that $\mathrm{PN}$ coefficient adjustments have on structure stability. In particular, the consideration of the transverse flexural stiffness of the slabs associated with the increase of the effective stiffness considered for them, assumes great relevance in the stability of the structure.

In the MOD0203 model, the SISE analysis module of the CAD / TQS program was again used, and the "springs" that simulate soil stiffness were incorporated into the space frame. For the second series models, $50-60 \mathrm{~cm}$ diameter CFA piles were adopted for the tower columns and $30 \mathrm{~cm}$ for the 'dying' columns in the foundation. The calculation method for estimating the resistant capacity of the ground pile system adopted was that of Alonso [10] apud Manual TQS (2013) [12]. Table 5 and Table 6 present the results found for MOD0203 for the instability and quantitative parameters of the columns respectively.

The results of Table 5 reinforce the observations presented for the first series models, in particular the fact that by disregarding the SSI in the analysis of the stability of tall buildings formed by flat slabs, the designer would be taking a significant stance against safety and the proper functioning of the designed structure.

Finally, adopting all the criteria and parameters that contribute to the stabilization of the structure, besides the SSI, the model MOD0204 was elaborated. Again a sequence of attempts, with successive manual adjustments of the cross sections of the columns, was performed until one $\gamma_{z}$ coefficient of less than 1.3 was obtained. Particularly in this model, in addition to the adjustment in the column sections, beams were used throughout the floor plan 


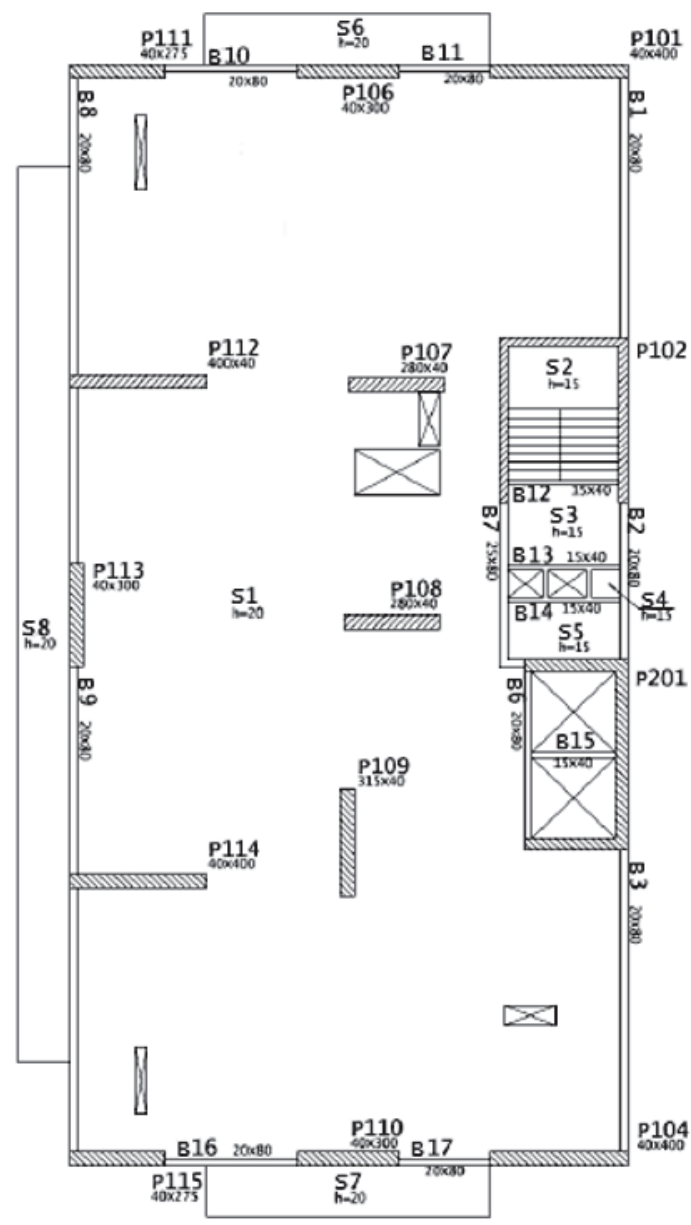

Figure 6

Floor plan of pavings - final model of section

contour of the standard floors (levels), as shown in Figure 6. The results obtained for MOD204 are presented in Table 5 and Table 6. As with model MOD0104, the total values of concrete consumption and forms in Table 6 include the amounts of plinth beams and piling foundation blocks, elements not considered in the reference model (MOD0200). As can be seen, there was an increase of $8.63 \%$ when compared to MOD203 due to the need to resize the structure in order to stabilize it.

\section{Conclusion}

After analyzing the results presented here, it can be concluded that the physical nonlinearity coefficients of the elements, the slab transverse stiffness and the discretization of the slab and column meeting area contribute effectively to the reduction of $\gamma_{z}$ and $\alpha$, as previously verified by Feitosa and Alves (2015) and Passos et al (2016).

Considering the effect of soil-structure interaction makes the structure more flexible, which was to be expected, but greatly increases the $\gamma_{z}$ parameter so that it is required superstructure supersizing or even a general change in launch initially proposed. Thus, it is noted that the analysis of this effect is important due to its great influence, although it is not adopted in the day-to-day practice of the calculation offices.

It is noteworthy that the analysis of the soil structure interaction was performed only for two building models and, therefore, it is necessary to analyze more models, with different types of buildings, in order to observe their behavior and effectively verify the influence on the final project.

\section{References}

[1] FRANCO, M.; VASCONCELOS, A. C. D. Avaliação Prática dos Efeitos de $2^{\mathrm{a}}$ Ordem em Edifícios Altos. Colloquium on the CEB-FIP MC 90, COPPE/UFRJ. ed. Rio de Janeiro: [s.n.], 1991.

[2] ASSOCIAÇÃO BRASILEIRA DE NORMAS TÉCNICAS - NBR6118. Projeto de estruturas de concreto - Procedimentos. ed. Rio de Janeiro, 2014.

[3] PASSOS, V. M.; FEITOSA, L. A.; ALVES, E. C.; AZEVEDO, M. S. Instability Analysis of Tall Buildings with Prestressed and Waffle Slabs. Revista IBRACON de Estruturas e Materiais, v. 9, p. 244-252, April 2016.

[4] FREITAS, F. C.; LUCHI, L. A. R. FERREIRA, W. G. Global Stability Analysis of Structures and Actions to Control their Effects. Revista IBRACON DE ESTRUTURAS E MATERIAIS, São Paulo, v. 9, p. 192-213, April 2016.

[5] FEITOSA, L. A.; ALVES, E. C. Study of Global Stability of Tall Buildings with Prestressed Slabs. Revista IBRACON DE ESTRUTURAS E MATERIAIS, São Paulo, v. 8, p. 196-224, April 2015.

[6] KIMURA, A. Informática Aplicada em Estruturas de Concreto Armado. São Paulo: Editora PINI, 2007.

[7] ASSOCIAÇÃO BRASILEIRA DE NORMAS TÉCNICAS - NBR6120. Cargas para o cálculo de estruturas de edificações. ed. Rio de Janeiro, 1980.

[8] AOKI, N.; VELLOSO, D. A. An approximate method to estimate the bearing capacity of piles. In: PAN AMERICAN CSMFE, 5., 1975, Buenos Aires. Proceeding. Buenos Aires, v. 1, 1975

[9] ASSOCIAÇÃO BRASILEIRA DE NORMAS TÉCNICAS NBR6122. Projeto e Execução de Fundações . ed. Rio de Janeiro, 2010.

[10] ALONSO, U.R. (1996). Estacas hélice contínua com monitoração eletrônica: previsão da capacidade de carga através do ensaio SPTT. $3^{\circ}$ Seminário de Engenharia de Fundações Especiais e Geotecnia. São Paulo, 2: $141151,1996$.

[11] FEITOSA, L. A., Estudo da Estabilidade Global de Edifícios de Multiplos Andares com Lajes Lisas, Dissertação de Mestrado, Universidade Federal do Espírito Santo, 2016.

[12] MANUAIS CAD/TQS. TQS Informática LTDA. São Paulo, 2013. 